\title{
The Role of Dietary Olive Oil from the Islamic and Scientific Perspectives
}

\author{
Syed A. Hussain, Ph.D., \\ Oak Brook, IL
}

DOI: http://dx.doi.org/10.5915/22-2-13551

\begin{abstract}
Health authorities have advised Americans to modify their diet in order to reduce the risk of heart disease and cancer. The dietary goals for the U.S. suggest reducing average dietary fat to $30 \%$ of total energy, reducing cholesterol to $300 \mathrm{mg}$ per day, and replacement of saturated fatty acids by polyunsaturated or monounsaturated fatty acids.

Monounsaturated fats have been the object of considerable nutritional interest, as epidemiological studies have determined that people in Mediterranean countries, where the predominant oil consumed is olive oil (a highly monounsaturated oil), suffer a very low incidence of cardiovascular disease.

A methodology is urgently needed for assessment of adherence to fat-controlled diets in free-living subjects, both long term and daily or even from meal to meal. In this respect, the Holy Qur'ān and the Sunnah of the Prophet Muhammad (PBUH) offer great promise. The aim of this undertaking is to present a survey of literature on the role of dietary olive oil from an Islamic perspective.
\end{abstract}

Key words: Olive oil, monounsaturated fatty acids, lipoprotein, cholesterol, Islamic teachings.

Oils have held a unique, universal appeal that is well entrenched in the history of culinary science, and have yet to be matched by any other food component. Oil confers a host of properties including flavor and a rich, smooth texture that improves the palatability of foods. Because of these properties, some cultures historically have regarded various oils as luxuries. Butter oil, for example, was one of these foods and was banned during Lent during the Middle Ages.

Oils also have been hallowed for other than strictly culinary purposes. In mythologies, butter is associated with virility and procreation. Medicinal qualities were ascribed to oils by the ancient Greek philosopher Democritus, whose prescription for good health was "honey on the inside, olive (oil) on the outside." Recognizing the lubricant and

From Swift-Ekrich, Inc., Oak Brook, IL.

Reprint Requests: Syed A. Hussain, Ph.D.

Swift-Ekrich, Inc.

1919 Swift Drive

Oak Brook, IL 60522 "healthful" properties of oil, the ancient Greeks and Romans rubbed it on their skin after bathing and before wrestling to make their muscles supple.

Today, oils are recognized for their nutritional, functional, and organoleptic properties. As the most concentrated source of energy, they supply $9 \mathrm{kcal} / \mathrm{g}$, which is more than twice that provided by proteins and carbohydrates. Oils act as carriers of fat-solube vitamins. They also aid in the transfer of heat to foods which are fried, and they contribute to a feeling of satiety after eating.

Oils belong to the chemical class of compounds called lipids. Lipids constitute one of the three major components of foods aand are recognized as essential nutrients in the human diet. Olive oil, which until recently was considered a specialty item, is one of the most ancient oils. It is obtained from the fruit of the evergreen tree, olea europa, by a crushing and pressing process. It takes $1300-2000$ olives to make one quart of olive oil.'

The Holy Qur'ān, the sacred text of Islam, contains revelation made by Allāh (God) to Muhammad (PBUH). The Qur'ān mentions olives and olive oil in the following surahs (verses): 
"Also a tree springing out of Mount Sinai which produces oil, and relish for those who use it for food.",2

"Allāh is the light of the heavens and the earth. The parable of His light is as if there were a Niche and within it a lamp; the lamp enclosed in glass; the glass as it were a brilliant star lit from a blessed tree, an olive, neither of the East nor of the West whose oil is well - nigh luminous, though fire scarce touched it; light upon light. Alläh does guide whom $\mathrm{He}$ will to His light. Allāh does set forth parables for men, And Allāh does know all things.",

"By the fig and the olive and the Mount of Sina, and this city of Security we have indeed created man in the best of molds." ${ }_{4}$

According to the Hadith, the sayings and practices of Prophet Muhammad (PBUH), 'Abū 'Usaid alAnșāi reported Allāh's messenger as saying, "Eat olive oil and anoint yourselves with it, for it comes from a blessed tree"s

In our technology-based modern society, which attempts to rationalize every fact of life, it is quite pertinent that the knowledge contained in the holy scriptures is having moral bearing on scientific thought for direction and development. In view of the current interest in olive oil, it is absolutely essential that the Holy Qur'ān and the traditions of the Prophet (PBUH) be given due credit. Also, it is important to extend our knowledge about the essentiality of olive oil in humans. After all, science and religion seek values to make human life meaningful and purposeful.

Scientific studies are emerging on the effects of olive oil as a natural source of oleic acid on lipid metabolism..$^{6} 7$ In Mediterranean countries, in spite of high average fat intake ( $40 \%$ of total calories), coronary heart disease (CHD) rates and plasma cholesterol levels are relatively low. ${ }^{8-10}$ In these countries, the usual diet is high in olive oil, which is rich in monounsaturated fatty acids (oleic acid).

For the same total cholesterol levels, death rate from CHD is lower in Mediterranean countries than in other countries such as Finland and the United States, ${ }^{11}$ suggesting that the influence of diet may simply be related to plasma and low-density lipoprotein (LDL) cholesterol levels, but also to different atherosclerosis risk factors. ${ }^{12}$ For the first time, health authorities such as the American Heart Association $^{13}$ have recommended olive oil in the treatment of hyperlipidemia in adults.

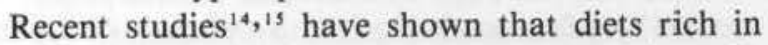
monounsaturated fatty acids, especially oleic acid, produce favorable changes in the concentrations of
Figure 1. Comparison of Dietary Fats

\begin{tabular}{|c|c|c|}
\hline Dietary Fat & $\begin{array}{c}\text { Cholesterol } \\
\text { mg/Tbsp }\end{array}$ & $\begin{array}{c}\% \text { Monounsaturated } \\
\text { Fat Content }\end{array}$ \\
\hline Canola Oil & 0 & $58 \%$ \\
\hline Safflower Oil & 0 & $13 \%$ \\
\hline Sunflower Oil & 0 & $20 \%$ \\
\hline Corn Oil & 0 & $25 \%$ \\
\hline Olive Oil & 0 & $77 \%$ \\
\hline Soybean Oil & 0 & $24 \%$ \\
\hline Peanut Oil & 0 & $48 \%$ \\
\hline Cottonseed Oil & 0 & $19 \%$ \\
\hline Lard & 12 & $47 \%$ \\
\hline Palm Oil & 0 & $39 \%$ \\
\hline Beef Tallow & 14 & $44 \%$ \\
\hline Butterfat & 33 & $30 \%$ \\
\hline Coconut Oil & 0 & $6 \%$ \\
\hline
\end{tabular}

Taken from Agricultural Handbook No. 8-4 and Human Nutrition Information Service, United States Department of Agriculture, Washington, DC, 1979.

serum lipoproteins. Other studies ${ }^{16,17}$ have suggested that increased consumption of oleic acid in the form of olive oil, at the expense of either saturated fatty acids or carbohydrates, is a proper approach to lowering coronary heart disease risk.

Figure 1 shows the cholesterol and monounsaturated fatty acid composition of olive oil compared to other representative oils. It is worth noting that of all the oils, only olive oil contains $77 \%$ monounsaturated fat.

Recent studies also suggest that diets rich in the monounsaturated fatty acid, oleic acid, are worthy of extensive investigation. Such diets might serve as an alternative to the more classical diets designed to reduce coronary heart disease. There is scientific evidence that dietary oleic acid does not lower high density lipoprotein (HDL) cholesterol when compared to the polyunsaturated fatty acid, linoleic acid. ${ }^{16,17}$ The replacement of saturated fatty acids by carbohydrates and monounsaturated fatty acids effectively decreases LDL cholesterol. However, carbohydrates lower HDL cholesterol whereas monounsaturated fatty acids leave HDL levels unchanged. ${ }^{18,19}$ Thus, substitution of monounsaturated for saturated fatty acids could be more advantageous than replacement of saturated fatty acids by either polyunsaturated fatty acids or carbohydrates.

A study by the Department of Human Nutrition, 
Agricultural University and the Department of General Internal Medicine, University of Nijmegen in the Netherlands compared the benefits of a diet rich in olive oil to one high in carbohydrate and fiber. ${ }^{20}$

Forty-eight healthy men and women consumed a baseline diet high in saturated fat for 17 days. For the next 36 days half the subjects consumed a diet rich in olive oil $(41 \%$ total fat and $24 \%$ monounsaturated fat), and half consumed a diet high in complex carbohydrates and fiber $(22 \%$ total fat and $65 \%$ carbohydrate).

Total cholesterol, LDL cholesterol, and $\mathrm{HDL}_{2}$ cholesterol levels decreased in subjects on both diets. Levels of $\mathrm{HDL}_{3}$ cholesterol decreased among the carbohydrate group but increased among the olive oil group. VLDL cholesterol decreased in the olive oil group but increased in the carbohydrate group.

In addition, levels of apolipoproteins changed favorably in the olive oil group (apolipoprotein A1, apo A1, increased and apolipoprotein B, Apo B, decreased). In the carbohydrate group, the reverse occurred (apo A1 decreased and apo B increased). The latter changes resulted in a $10 \%$ decrease in the ration of apo A1 to apo B in the carbohydrate group, but a $16 \%$ increase in the ratio in the olive oil group. These results are significant, since some studies suggest that concentrations of apolipoproteins and $\mathrm{HDL}_{2}$ cholesterol are better indicators for risk of atherosclerosis than total cholesterol and HDL cholesterol.

The researchers conclude that an olive oil rich diet more favorable affects the lipoprotein risk profile for coronary heart disease than diet high in complex carbohydrates.

In another study at the Institute of Internal Medicine and the Clinical Medica I, University of Padua, the Military Hospital of Padua, and the Institute of Chemical and Clinical Microscopy and the Patologia Medica, University of Verona, Italy, the effects on serum lipids and lipoproteins of an olive oil-enriched diet were compared with a low fat diet. ${ }^{21}$

Eleven young male subjects were studied in a metabolic ward at the Military Hospital of Padua, Italy. All but three had plasma total cholesterol levels

$5.2 \mathrm{mmol} / \mathrm{L}$ at the time of admission; two had plasma cholesterol levels $6.5 \mathrm{mmol} / \mathrm{L}$ without xanthomas, atherosclerotic lesions, or family history of familial hypercholesterolemia. The mean cholesterol level value was $5.90 \pm 0.80 \mathrm{mmol} / \mathrm{L}( \pm \mathrm{SD})$. Levels of plasma triglycerides were within the normal range for Italy. No subjects had history or clinical evidence of atherosclerotic, liver, kidney, gastrointestinal, or endocrine disease.

All subjects were studied at the end of two 3-week dietary periods. Throughout the study, the participants had three meals per day: breakfast, lunch, and dinner at 0800 hours, 1230 hours, and 1930 hours, respectively. For the first three weeks, subjects received diet I (low-fat diet); for the second 3 weeks, they received diet II (olive oil-rich diet). During the whole trial the daily caloric intake was evaluated so that each subject maintained a constant body weight. Diet II was obtained by eliminating all separable (seasoning and cooking) fats from diet I and by adding $100 \mathrm{~g}$ of olive oil. Average fat removed from diet I was $60 \mathrm{~g} ; 70 \mathrm{~g}$ of carbohydrates also were removed to maintain the same caloric intake. Total caloric intake and body weight remained constant in each subject during the trial. The subjects were permitted to walk around the hospital premises but not to engage in any form of strenuous physical activity.

At the end of each 3-week dietary period, blood samples were collected after a 12-hour fast, and serum was separated by low-speed centrifugation $(100 \times \mathrm{g}, 10 \mathrm{~min})$ after one hour of clotting. Each sample was analyzed for total cholesterol, triglycerides, apoproteins A1 and B, HDL cholesterol, and $\mathrm{HDL}_{3}$ cholesterol. A significant decrease $(12.2 \%)$ was noted in the LDL cholesterol. $\mathrm{HDL}, \mathrm{HDL}_{2}$ and $\mathrm{HDL}_{3}$ cholesterol and serum apo A1 mean levels remained unchanged after the olive oil diet. The mean LDL:HDL cholesterol ratio decreased by $9.4 \%$. Olive oil administration for 21 days did not affect the cholesterol saturation index of bile, which was $0.804 \pm 0.17$ after diet I and $0.796 \pm$ 0.11 after diet II. Similarly, gall bladder volume and motility were not influenced. In fact, fasting volumes were $19.56 \pm 7.08 \mathrm{ml}(\mathrm{x} \pm \mathrm{SD})$ before and $19.88 \pm$ $9.6 \mathrm{ml}$ after diet II. Residual volumes after meal were $9.93 \pm 5.05 \mathrm{ml}$ before and $9.22 \pm 7.03 \mathrm{ml}$ after diet II, corresponding to 51 and $50 \%$ reduction, respectively (difference was not significant).

Two conclusions can be drawn from this study. First, olive oil represents a good source of natural fat for the dietary control mild hypercholesterolemia. In fact, it is as effective as polyunsaturated fatty acidenriched vegetable oils in reducing serum cholesterol levels without interfering with HDL metabolism. Second, raising the fat content (percent of total calories) of the diet by using olive oil represents a good strategic approach for the dietary lowering of cholesterol levels.

Elevation of blood cholesterol levels is a major cause of coronary artery disease. It has been established beyond a reasonable doubt that lowering definitely elevated blood cholesterol levels (specifically blood levels of low density lipoprotein [LDL] cholesterol) will reduce the risk of heart attacks caused by coronary heart disease. Saturated fats have been shown repeatedly to raise plasma cholesterol and LDL levels. Monounsaturated fatty acids would be a good substitute for saturated fatty acids. The former do not reduce plasma cholesterol quite as much as polyunsaturates do, but they nevertheless have certain potential advantages. The human 
body synthesizes considerable quantities of monounsaturated fatty acids, and thus these fatty acids probably do not possess any inherent "toxicity". Large amounts of monounsaturates are ingested as olive oil in the Mediterranean region without evidence of adverse effects. Indeed, the prevalence of CHD in this region of the world is relatively low compared to countries where ingestion of saturated fat is high. ${ }^{22,8}$

At present, no inexpensive sources of natural monounsaturated fats similar to olive oil are readily available in the U.S., but there are several potential sources of monounsaturates which could be explored were they deemed a useful substitute for saturated fat. With regard to the safety of various dietary fats, it must be stressed that olive oil has been used without any adverse effect for thousands of years as the major fat component in the diets of Mediterranean populations.

\section{Conclusion}

Olive oil represents a good source of natural fat for the dietary control of mild hypercholesterolemia. Raising the fat content (percent of total calories) of the diet by using olive oil represents a good strategic approach for the dietary lowering of cholesterol level. In any event, it is reassuring that the various regions of Mediterranean countries, high intakes of fat in the form of olive oil do not appear to affect health negatively. On the contrary, the liberal use of olive oil might be, in part, responsible for the low rates of coronary heart disease in these countries.

In biblical times, "holy" oils usually included a base of olive oil with myrrh, frankincense, sweet calamus, and cassia (cinnamon) added. When used in anointing, the precious olive oil and the sweetsmelling liquid contributed to the religious effect. ${ }^{23}$ The Bible, the Talmud and the Qur'an all speak of the olive and olive oil in various terms, as a good oil, and for anointing for the body. Now science has given full praise about the curative properties of olive oil. A learned scholar and scientist of our time has said this in a very beautiful way: " . . . Mankind has only begun to unravel the mysteries of substances the Holy Qur'ān described." 24

\section{References}

1. Lang JH: Handpicking the right olive oil. Restaurants USA, June/July 1987:28.

2. Glorious Qur'ān, Chapter 23, Verse 20.

3. Glorious Qur'ān, Chapter 24, Verse 35.

4. Glorious Qur'ān, Chapter 95, Verses 1-4.

5. 'Ibn Majah, Muhammad b. Yazid: "Sunan 'ibn Mājah" (Arabic) Cario, Egypt: 'Isā al Halabī Publishing Company (no date mentioned).

6. Sirtori CR, Tremoli E, Gatti E, et al: Controlled evaluation intake in the Mediterranean diet: Comparative activities of olive oil and corn oil on plasma lipids and platelets in high risk patients. Am J Clin Nutr 1986; 44: 635-642.

7. Schlierf G, Nikolaus T, Stiehl A, et al: Zur wirkung lipidspiegelsenkender kostformen auf gallenlipide and plasmalipopriteine bei normal personen. Schweiz Med Wochenschr 1979; 109: 1743-1747.

8. Keys A: Coronary heart disease in seven countries. Circulation 1970; 41 (Suppl 1): 1-211.

9. Grundy SM, Billheimer D, Blackburn $\mathrm{H}$, et al: Rationale of the diet-heart statement of the American Heart Association: Report of Nutrition Committee. Circulation 1982; 65: 839A-854A.

10. Grundy SM, Gotto AM, Bierman EL, et al: Recommendations for the treatment of hyperlipidemia in adults: A joint statement of the Nutrition Committee and the Council on Arteriosclerosis of the American Heart Association, Arteriosclerosis 1984; 4: 445A-468A.

11. Reference 8, 1-211.

12. Reference 9,839A-54A.

13. American Heart Association, Diet and Coronary Heart Disease. A statement for physicians and other health professionals prepared by the Nutrition Committee of the Steering Committee for Medical and Community Programs of the Amrican Heart Association, Dallas, 1978.

14. Grundy SM: Comparison of monounsaturasted fatty acids and carbohydrates for lowering plasma cholesterol. N Engl J Med 1986; 314: 745-748.

15. Mensink RP, Katan MB: Effect of monounsaturasted fatty acids versus complex carbohydrates on high density lipoproteins in healthy men and women. Lancet 1987; 1:122-125.

16. Versley B, Gustafesson IB, Boberg J, Karlstrom B, Lithall H, Werner I: Substituting polyunsaturated fat for saturated fat as a single change in a Swedish diet: Effect on serum lipoprotein metabolism and glucose tolerance in patient with hyperlipoproteinemia. Eur J Clin Invest 1980; 10:193-202.

17. Refence 6: 635-642.

18. Reference 14: 745-748.

19. Reference 15: 122-125.

20. Mensink R, de Groot M, Van den Brocke I, et al: Effects of monounsaturated fatty acids versus complex carbohydrates on serum lipoproteins and apoproteins in healthy men and women. Metabolism 1989; 38: 172-178.

21. Baggion G, Pagnan A, Muraca M, et al: Olive oil-enriched diet: Effect on serum lipoprotein levels and biliary cholesterol saturation. Am J Clin Nutr 1988; 47: 960-964.

22. Reference 8 (Suppl I): I-1.

23. Schwartz G: Food Power. New York: McGrawHill Book Company, 1979: 52.

24. Sakr AH: Honey: A Food and a Medicine. Lombard, IL: Foundation for Islamic Knowledge, 1976: 27. 